Mariz Tadros

\title{
VICISSITUDES IN THE ENTENTE BETWEEN THE COPTIC ORTHODOX CHURCH AND THE STATE IN EGYPT (1952-2007)
}

This paper asserts that in 1952 an entente was forged between the Coptic Orthodox Church and the Egyptian government that provided the church with concessions in return for its political allegiance to the regime. The period prior to 1952 also witnessed the Coptic church leadership forging alliances with regimes in power; however, its ability to represent Copts vis-à-vis the state was rivaled by other Coptic voices in civil society such as the Majlis al-Milli. From 1952 on, the inhibition of Copts' voices in civil society increased the church's political power, and it developed into the undisputed voice representing the Coptic community. The relationship between church and state in the past fifty years has been volatile, affected not only by the nature of the relationship between leaders of the church and state but also by the emergence of other important players within and outside these two entities. Strains characteristic of the period leading up to the temporary dissolution of the entente in the 1970s are becoming visible today in the church-state relationship. This paper suggests that the current entente between the church and the state is being stretched to its limit although it is not likely to be dissolved. 